\title{
Effects of Variations in Hormonal Treatments Upon In Vitro Regeneration Potential in Embryo Explants of Arenga pinnata
}

\author{
Shamsiah Abdullah*, Siti Nurain Roslan \\ Faculty of Plantation and Agrotechnology, Universiti Teknologi MARA, Cawangan \\ Melaka, Kampus Jasin, Malaysia
}

\begin{abstract}
One of the challenges related to propagation of Arenga pinnata is its lengthy period of seed dormancy. In this study, in vitro regeneration was carried out to determine the effect of hormonal treatment on the embryo explant of Arenga pinnata. Embryos were surface sterilized and cultured into different media supplemented with various hormones concentrations and combinations. Each treatment contained of Kinetin $(\mathrm{KN})$ hormone $(1.0,2.0$, and $3.0 \mathrm{mg} / \mathrm{l})$ and in combination with indole-3-acetic acid (IAA) of $0.1,0.2,0.3 \mathrm{mg} / \mathrm{l}$. The height of plumule and length of radical was observed and recorded. Treatment $8(3 \mathrm{mg} / \mathrm{ml} \mathrm{KN}+0.1 \mathrm{mg} / \mathrm{ml} \mathrm{IAA})$ showed $59.09 \%$ in plumule height increment while treatment $4(1 \mathrm{mg} / \mathrm{ml} \mathrm{KN}+0.3 \mathrm{mg} / \mathrm{ml} \mathrm{IAA})$ showed the highest radical increments with $93.62 \%$. The knowledge gained in this study consequently helps us to better understand the role of KN and IAA in the in vitro regeneration protocol. Since in vitro method able to produce higher number of in vitro seedlings at one time, it is important to establish the in vitro regeneration protocol for this plant.
\end{abstract}

Keywords: Arenga pinnata, sugar palm, in vitro regeneration, plant growth regulator.

*For correspondence: shamsiah3938@uitm.edu. my

Received: 7 January 2021 Accepted: 15 October 2021

(C) Copyright Abdullah. This article is distributed under the terms of the Creative Commons Attribution License, which permits unrestricted use and redistribution provided that the original author and source are credited.

\section{Introduction}

Arenga pinnata a member of Palmae family, also known as sugar palm, arenga palm, "enau" or 'kabung' is an economically useful plant because all parts of sugar palm can be turned into valuable things [1]. Sugar palm is a wonderful source of food, beverages, biofibres, biopolymers, and bio composites [2]. The sap extracted is an alternative for sugar while through fermentation process, byproduct obtained are vinegar and wine. In addition, the immature fruits are processed into canned fruit and the barks of the plant are manufactured into cordage. Generally, sugar palm trees grow near human settlement and are situated down the rivers in rural areas in Malaysia. The plantation size is approximately 892 hectares [3]. The first flower of sugar palm would be as early as five to six years, but on average it takes around ten to twelve years. The life span of the sugar palm ranges between twelve to twenty years old depending on the harvest environment. Apart from this, Arenga pinnata is typically propagated using fruit seedlings. However, a lot of attention and care needs to be paid to the seed cultivation of this crop. Another challenge faced is that the propagation is hindered by the limitations of recalcitrant seeds and prolonged dormancy [4]. To add on to the problems, the rate of germination is still low. All these limitations lead to uneven growth, slow seedling growth and development upon germination, therefore no interest to plant this crop commercially despite the various benefits they offer. In terms of the farmers there have been low availability of reliable information on palm sugar, long juvenility coupled with a short lifespan for harvesting the plant all adds up to the declining attraction for farmers and businessman to venture into 
commercializing palm sugar as plantation. On the other hand, nursery germination of sugar palm trees is considered as low and highly inadequate. In order to conserve and maintain the viability and freshness of the seed of sugar palm very particular and specific temperature, humidity and storage requirement are to be checked to ensure the viability and ability of the seed to germinate. To sustain a healthy number of sugar palm through cultivation, the common method used were to collect the wild seedlings from natural regeneration which is then nurtured as nursery seedlings. However, this brings a new problem as the wild seedlings production depended greatly on natural regeneration; though wild domestication of sugar palm can be least costly as no labor is required for seeds planting, the intensive harvest of sugar palm fruits diminishes the source of seed for natural regeneration prominently [25]. For all these reasons, it is difficult for Arenga pinnata to be considered for commercial farming

The declining in the number of sugar palm trees should be the concern because if this keeps on going there is a possibility of extinction of the sugar palm trees in the future. Hence, further research to develop organized and supplementation planting and conservation efforts of the seedlings is crucial. As much as the stated constraints in seed breeding of sugar palm trees is influenced, mainly uncooperative seed and dormancy, seed propagation may play an important role in sugar palm breeding especially for the variability and germplasm conservation purposes. These all will depend on the plant species; seed dormancy may last for only a few days or if several years. The alternate method to overcome the issue in generating mass production of sugar palm with uniform and rapid growth is through in vitro regeneration supplemented with PGRs hormone. It is naturally occurring that all plants release hormones in correspondence with their environment. These hormones functions in the regulation of growth, development, and metabolism. The location where hormones are normally made were at a variety of sites such as roots, buds, and leaves, and are relocated to targeted sites after combining with specialized receptors [16]. Hormones are responsible for different task and command on the plant i.e., manipulate plants reactions to environment strain, cell division, cell elongation and cell differentiation. They can produce several reactions conditional upon targeted tissues, plant's developmental stages, relative concentrations, uptake and storing of water and other nutrients, and climatic conditions [17]. Hormones exists in the plant tissues, and the process of isolating, identifying, and extracting the hormones for studies and laboratory tests has been challenging as the amount that are inside the plant are rather low. However, with artificial hormones, these processes can be monitored and regulated, such as the formation and growth of buds, flowers, fruits and roots [18]. The industrial manufacture of the artificial hormonal products, also known as plant growth regulators (PGRs). Plant growth regulators are extensively utilized in agriculture, viticulture, and horticulture to boost growth in non-ideal or stressful conditions (e.g., short growing seasons, low soil fertility, and diseases) and to improve yields and ease of harvesting (e.g., prevention of immature fruit drop, accelerating maturity, and ripening etc. [19]. Cytokinin and auxin are common plant growth regulators used in plant tissue culture especially in vitro protocol $[5,6]$. Recent study highly suggested the use of kinetin (KN) relative to Zeatin, Thidiazuron (TDZ) and 6-Benzylaminopurine (BAP) to achieve the highest percentage of regeneration (83\%), the highest number of shoot/explant $(7.93$ nos), and the highest shoot length $(3.61 \mathrm{~cm})$ for the nodal explant of cucumber [6]. In comparison, other previous work showed that kinetin with a concentration of $3.0 \mathrm{mg} / \mathrm{l}$ and $0.6 \mathrm{mg} / \mathrm{l}$ of NAA had the highest result [7]. The experiment was conducted with $\mathrm{KN}$ tested with 0,1.0, 2.0, $3.0 \mathrm{mg} / \mathrm{l}$ and NAA with $0,0.2,0.4,0.6 \mathrm{mg} / \mathrm{l}$. Whereas IAA is an auxin form. Root and shoot development of higher plant relies on the ration of cytokinin: auxin. $\mathrm{KN}$ as a cytokinin for shoot development hormone and IAA as an auxin hormone to induce rooting. The study indicated that pigeon pea treated with IAA $10 \mathrm{~mm}$ in pre-treatment $(87.67 \pm 0.33 \mathrm{~cm})$ had a significance difference with respect to control $(68.00 \pm 0.58 \mathrm{~cm})$ in terms of plant height [8]. Another studies on application of KN and IAA in a field study to improve the drought stress tolerance in four rice genotypes (Gharib', 'Khazar', 'Sepidrood' and 'IR83750-131-1'('IR83750')) showed manipulation of amount used for IAA and KN are vital in developing the optimum drought tolerance ratio where highest percentage of relative water content (RWC) in "Sepidrood" (51.26\% and 50.19\% treated in IAA and KN respectively) and lowest electrolyte leakage (EL) with $(25.79 \%$ and $27.59 \%$ treated in IAA and KN respectively) [9]. Hence, the aim of this study is to determine the optimum combination of KN and IAA on sugar palm culture and the response towards the hormone combination. 


\title{
Materials and methods
}

\author{
Preparation of Growth Medium and Explant
}

A wide variety of microbial pollutants are present on the surface of the plant sections. The appearance of any pollutant can interfere with the development of explants or cultures and contamination of fungal or bacterial explants in plant cultures is typically detected 1-14 days after culturing [5]. Sterilization or disinfection of tissues is therefore important for the eradication of surface microorganisms.

Prior to the preparation of an explant, the growth medium was prepared as described by [1]. Firstly, 70 $\mathrm{ml}$ of deionized or distilled water was poured into a bottle. After that, $0.44 \mathrm{~g}$ of Murashige and Skoog (1962) (MS) powder and $3 \mathrm{~g}$ sucrose were added and allowed to dissolve completely. Next, the medium volume was brought to $100 \mathrm{ml}$. The $\mathrm{pH}$ was adjusted to 5.8 with $\mathrm{NaOH}(1 \mathrm{M})$ or $\mathrm{HCl}(1 \mathrm{M})$. About $0.8 \mathrm{~g}$ of agar was applied to the medium and autoclaved at $1210 \mathrm{C}$ for 20 minutes. Then, the medium was cooled sufficiently and poured into sterile containers in a horizontal laminar air flow chamber, allowing the agar to solidify. The same steps were repeated by adding 1.0, 2.0, and $3.0 \mathrm{mg} / \mathrm{l}$ of kinetin and $0.1,0.2$ and $0.3 \mathrm{mg} / \mathrm{l}$ of IAA, respectively. These hormones were added after sucrose had been added and allowed to dissolve completely.

The preparation of Arenga pinnata explant begin with fruit sterilization and followed a procedure according to [5]. This should be done first, as the embryo is too delicate to interact directly with chemical substances. The fruits were placed under running water for 30 minutes. The fruit was then soaked in a mixture of general bleach (Clorox) and distilled water for 10 minutes. The fruits were rinsed for few times with distilled water. The fruits were then taken to the laminar air flow chamber and soaked with $90 \%$ alcohol for 5 to 10 minutes. Then, the fruits were rinsed once with sterilized distilled water followed by soaking the fruits in $70 \%$ Sodium Hypochlorite added with a few drops of Tween 20 (is an emulsifier that is applied at the rate of 1 drop per $100 \mathrm{ml}$ of solution) for another 10 minutes. The fruits were then rinsed 3 times with sterilized distilled water.

\section{In Vitro Regeneration Process}

After the fruits were sterilized, the embryos were obtained by cutting the fruits endocarp and pulp. Next, the embryos were placed onto the medium supplemented with various concentration and combination of $\mathrm{KN}(1.0,2.0$ and $3.0 \mathrm{mg} / \mathrm{l}$ and IAA $(0.1,0.2,0.3 \mathrm{mg} / \mathrm{l})$. The culture was germinated in a culture room at the temperature of $25{ }^{\circ} \mathrm{C}$ with 16 hours photoperiods. The culture was allowed to grow up to eight weeks.

\section{Experimental Design and Statistical Analysis}

Each treatment was replicated five times with a single explant for each vial. The height of plumule $(\mathrm{cm})$ and length of radicle $(\mathrm{cm})$ were evaluated and recorded as a growth parameter once a week until 8week-old. The findings were subjected to analysis of variance (ANOVA) and Duncan New Multiple Range Test (DNMRT) at a 5\% probability level by using the Statistical Package for the Social Sciences (SPSS) version 21.

\section{Results and discussion}

Numerous studies have been established to illustrate the production of tissue culture from either the basal stem [9] and fruit [1,11] utilizing various PGRs such as 6-benzylaminopurine (BAP), 2, 4Dichlorophenoxyacetic acid (2,4-D) and KN related to multipurpose benefits from sugar palm. The current study therefore uses a mixture of $K N$ and IAA as PGRs to evaluate the growth of sugar palm from fruit as an explant. The embryo explant demonstrated a response to the hormone-free MS medium and a regeneration protocol using MS medium supplemented by varying concentration of KN and IAA to stimulate the growth of both radical and plumule tissue. All treatment supplemented with PGRs showed 
an improvement in the height of plumule and in the length of the radicals. The study began to show a response to the treatment as early as seven days after culture. The initial sizes of the embryos differ from one another.

In vitro plant requires the formation of a complete nutritional medium and for exploration of plant physiological processes; it needs the addition of effective plant growth regulators. Cytokinin are the hormones that act to promote cell division and expansion, induction of buds, differentiation, promote lateral bud sprouting and inhibition of senescence. While auxin was the hormone that facilitate cell division and root differentiation. Auxin induces cell division, cell elongation, and formation of callus in cultures. Furthermore, it promotes growth such as in the formation of roots and root length, thus causing plants to absorb more water and nutrients for plant grow [24].

The result of the study shows a growth of plumule as early seven day-olds (Figure 1). At the end of week 8 , the heights of plumules were in the range of $0.78 \mathrm{~cm}$ to $0.92 \mathrm{~cm}$ (Table 1). The application of $\mathrm{KN}$ at $1.0,2.0$ and $3.0 \mathrm{mg} / \mathrm{l}$ increase the activity cell division and expansion. Thus, the explant treats with $\mathrm{KN}$ increase higher compared to control. Cytokinins are synthesized in the roots and are mostly extracted from adenine, moving upward in the xylem (woody tissue) and passing through the leaves and fruits, where it's required for normal growth and cell differentiation. Applying $\mathrm{KN}$ as a cytokinin not only successful to tissue culture experiment but also to the field experiment such as those carried out by [12] where, $\mathrm{KN}$ is added to soybean crops caused dry mass accumulation increases, resulting in a high yield. In fact, embryos require an average of seven days to increase the plumule height by $0.1 \mathrm{~cm}$ from previous height. Even though different concentrations of $\mathrm{KN}$ have been used as treatments for the embryo, plumule growth does not seem differ from each other.
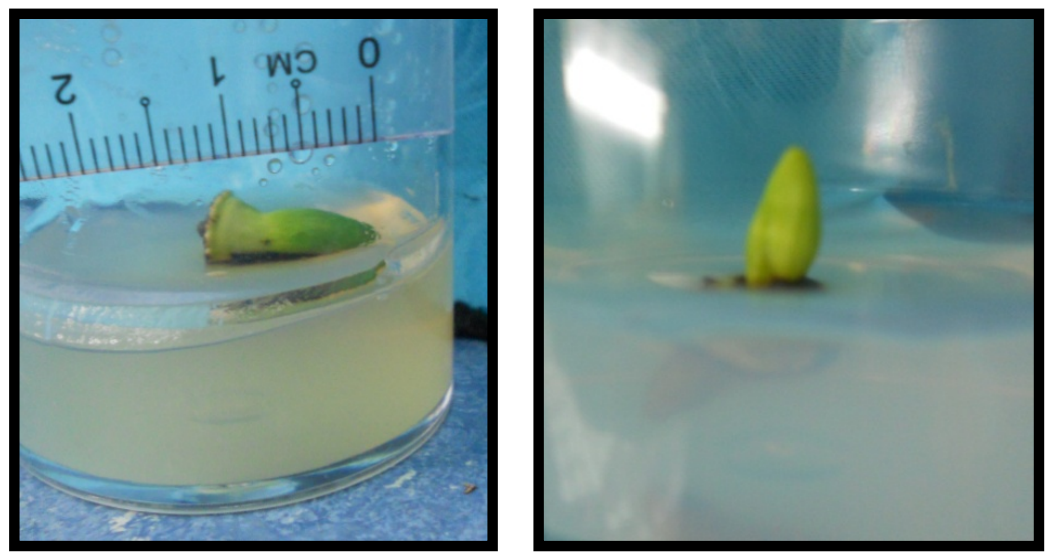

Figure 1. Plumule growths from embryo

Table 1. Average height of plumule $(\mathrm{cm})$ based on different treatment of $\mathrm{KN}$ and IAA for 8 weeks of culture

\begin{tabular}{ccccccccccc}
\hline KN & IAA & T & Week 1 & Week 2 & Week 3 & Week 4 & Week 5 & Week 6 & Week 7 & Week 8 \\
\hline 0 & 0 & 1 & $0.36 \pm 0.11^{\mathrm{a}}$ & $0.38 \pm 0.08^{\mathrm{a}}$ & $0.38 \pm 0.08^{\mathrm{a}}$ & $0.42 \pm 0.04^{\mathrm{a}}$ & $0.54 \pm 0.55^{\mathrm{a}}$ & $0.62 \pm 0.08^{\mathrm{a}}$ & $0.74 \pm 0.05^{\mathrm{a}}$ & $0.78 \pm 0.08^{\mathrm{a}}$ \\
1 & 0.1 & 2 & $0.46 \pm .011^{\mathrm{a}}$ & $0.50 \pm 0.12^{\mathrm{ab}}$ & $0.54 \pm 0.11^{\mathrm{b}}$ & $0.62 \pm 0.11^{\mathrm{bc}}$ & $0.64 \pm 0.11^{\mathrm{a}}$ & $0.74 \pm 0.09^{\mathrm{a}}$ & $0.82 \pm 0.08^{\mathrm{a}}$ & $0.90 \pm 0.14^{\mathrm{a}}$ \\
& 0.2 & 3 & $0.50 \pm 0.07^{\mathrm{a}}$ & $0.54 \pm 0.05^{\mathrm{b}}$ & $0.60 \pm 0.07^{\mathrm{b}}$ & $0.68 \pm 0.08^{\mathrm{c}}$ & $0.72 \pm 0.08^{\mathrm{a}}$ & $0.76 \pm 0.09^{\mathrm{a}}$ & $0.84 \pm 0.05^{\mathrm{a}}$ & $0.90 \pm 0.12^{\mathrm{a}}$ \\
& 0.3 & 4 & $0.40 \pm 0.10^{\mathrm{a}}$ & $0.44 \pm 0.13^{\mathrm{ab}}$ & $0.50 \pm 0.14^{\mathrm{b}}$ & $0.52 \pm 0.11^{\mathrm{ab}}$ & $0.60 \pm 0.10^{\mathrm{a}}$ & $0.66 \pm 0.05^{\mathrm{a}}$ & $0.76 \pm 0.11^{\mathrm{a}}$ & $0.84 \pm 0.05^{\mathrm{a}}$ \\
2 & 0.1 & 5 & $0.42 \pm 0.08^{\mathrm{a}}$ & $0.46 \pm 0.08^{\mathrm{ab}}$ & $0.52 \pm 0.08^{\mathrm{b}}$ & $0.60 \pm 0.07^{\mathrm{bc}}$ & $0.68 \pm 0.18^{\mathrm{a}}$ & $0.74 \pm 0.17^{\mathrm{a}}$ & $0.82 \pm 0.13^{\mathrm{a}}$ & $0.86 \pm 0.11^{\mathrm{a}}$ \\
& 0.2 & 6 & $0.46 \pm 0.11^{\mathrm{a}}$ & $0.52 \pm 0.13^{\mathrm{b}}$ & $0.60 \pm 0.10^{\mathrm{b}}$ & $0.66 \pm 0.05^{\mathrm{c}}$ & $0.70 \pm 0.07^{\mathrm{a}}$ & $0.76 \pm 0.05^{\mathrm{a}}$ & $0.88 \pm 0.08^{\mathrm{a}}$ & $0.92 \pm 0.11^{\mathrm{a}}$ \\
& 0.3 & 7 & $0.50 \pm 0.07^{\mathrm{a}}$ & $0.52 \pm 0.08^{\mathrm{b}}$ & $0.58 \pm 0.04^{\mathrm{b}}$ & $0.64 \pm 0.11^{\mathrm{c}}$ & $0.68 \pm 0.08^{\mathrm{a}}$ & $0.72 \pm 0.13^{\mathrm{a}}$ & $0.86 \pm 0.15^{\mathrm{a}}$ & $0.90 \pm 0.07^{\mathrm{a}}$ \\
3 & 0.1 & 8 & $0.36 \pm 0.11^{\mathrm{a}}$ & $0.42 \pm 0.04^{\mathrm{ab}}$ & $0.50 \pm 0.07^{\mathrm{b}}$ & $0.58 \pm 0.08^{\mathrm{bc}}$ & $0.64 \pm .015^{\mathrm{a}}$ & $0.72 \pm 0.15^{\mathrm{a}}$ & $0.84 \pm 0.15^{\mathrm{a}}$ & $0.88 \pm 0.15^{\mathrm{a}}$ \\
& 0.2 & 9 & $0.40 \pm 0.10^{\mathrm{a}}$ & $0.44 \pm 0.08^{\mathrm{ab}}$ & $0.50 \pm 0.07^{\mathrm{b}}$ & $0.56 \pm 0.05^{\mathrm{bc}}$ & $0.62 \pm 0.04^{\mathrm{a}}$ & $0.72 \pm 0.15^{\mathrm{a}}$ & $0.78 \pm 0.15^{\mathrm{a}}$ & $0.82 \pm 0.08^{\mathrm{a}}$ \\
& 0.3 & 10 & $0.46 \pm 0.11^{\mathrm{a}}$ & $0.55 \pm 0.07^{\mathrm{b}}$ & $0.58 \pm 0.05^{\mathrm{b}}$ & $0.62 \pm 0.05^{\mathrm{bc}}$ & $0.68 \pm 0.04^{\mathrm{a}}$ & $0.74 \pm 0.11^{\mathrm{a}}$ & $0.86 \pm 0.05^{\mathrm{a}}$ & $0.92 \pm 0.11^{\mathrm{a}}$ \\
\hline
\end{tabular}


However, based on Figure 2, it shows that treatment $8(3 \mathrm{mg} / \mathrm{ml} \mathrm{KN}+0.1 \mathrm{mg} / \mathrm{ml} \mathrm{IAA})$ had $59.09 \%$ plumule height increment, followed by treatment $1(0 \mathrm{mg} / \mathrm{ml} \mathrm{KN}+0 \mathrm{mg} / \mathrm{ml} \mathrm{IAA})$ and treatment 4 (1 $\mathrm{mg} / \mathrm{ml} \mathrm{KN}+0.3 \mathrm{mg} / \mathrm{ml} \mathrm{IAA}$ ) with increment of $53.85 \%$ and $52.38 \%$ respectively. There was a difference of around $5.00 \%$ in height between the two. There were 2 treatments that showed the least response towards the hormone which were treatments $3(1 \mathrm{mg} / \mathrm{ml} \mathrm{KN}+0.2 \mathrm{mg} / \mathrm{ml} \mathrm{IAA})$ and treatment $7(2 \mathrm{mg} / \mathrm{ml}$ $\mathrm{KN}+0.3 \mathrm{mg} / \mathrm{ml}$ IAA) with similar increments of $44.44 \%$. the difference between the highest treatment 8 of $59.09 \%$ with treatment 3 and 7 with the lowest height at $44.44 \%$ is around $15.00 \%$. This showed that the plumule height is influenced by a higher $\mathrm{KN}$ concentration but when the concentration of IAA was increase in intensity the effect as well of increased, $\mathrm{KN}$ seems to be masked and the height does not seem to show steady growth needed. In this study, the supplement of $\mathrm{KN}$ at $3 \mathrm{mg} / \mathrm{ml}$ in treatment 8 was higher in percentage of height increment. This might be due to the presence of optimum concentration of KN, which helps to enhance the expansion of the cell [15]. However, treatment 9 and 10 were the lowest relative to treatment 8 although they received the same concentration of $\mathrm{KN}$. The balance between IAA and KN should have the optimum ration and if some are over supply to the plant, it might have adverse effect on growth and development of the plant. The other explanation concentration of IAA may decrease the role of $\mathrm{KN}$ as the hormonal concentration increases. The physiological response tends to increase before the plant reaches the "saturation stage", where the higher concentration of the hormone does not affect the plant to provide the same rate of physiological response until reaching the saturation point. Therefore, applying a higher concentration of the hormone after the plant exceeds the saturation stage would only reduce the physiological reaction. This was in consistent with previous study by [20], which stated that the response of pigeon pea towards the treatment of IAA and $\mathrm{KN}$ are to be influenced by the concentration applied and the cultivars used of the seed. The optimum ratio of IAA and KN on Pigeon pea showed that it may possibly encourage both physiological and biochemical properties. Thus, this improved development and productivity of the pigeon pea. Obviously, exogenous growth regulators are administered to deliver a balance against endogenous hormones to be able to manipulate physiological responses such as stimulants of cell division and extension. Both processes affected by the hormone's auxin and cytokinin. Relatively lower auxin concentrations can stimulate shoots growth [23].

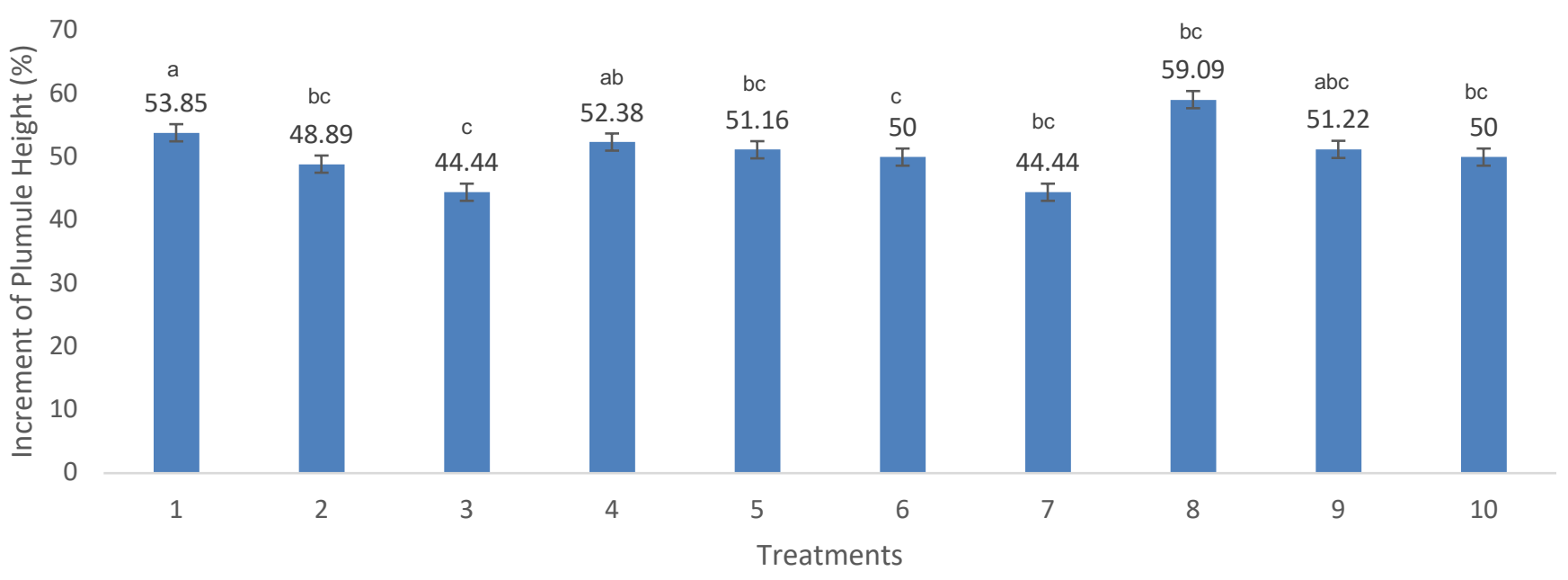

Figure 2. The effect of different combination of KN and IAA treatment on the plumule height (\%). The error bars represent the standard deviation of mean measurements for the plumule height.

Although the plumule tissue was the first tissue that showed a response toward the treatments, the radical tissue showed faster development once it started to develop. The radical started to develop at 28 days after culture (Figure 3). Only a few embryos exhibited radical developments on week 4 while the rest only start to develop radical tissue at week 5 . With the range of 0.06 until $0.1 \mathrm{~cm}$ initial radical length, later the radical length increased up to $1.2 \mathrm{~cm}$ at the end of week 8 (Table 2). The radical development showed an outstanding growth with $0.3 \mathrm{~cm}$ increment in 1 week. According to a study 
conducted by [12], IAA initiates a signal transduction pathway resulting in the production of secondary messengers that activate pre-existing $\mathrm{H}+$-ATPases and stimulates the expression of several genes related to growth and development. This supports the result, where treatment $9(0.2 \mathrm{mg} / \mathrm{ml}$ IAA) showed the longest radicle length at week 8. The application of IAA may affect the protein content of developing sugar palm embryo. Adequate amount of IAA supplied or already in plant can encourage the protein synthesis process in plant tissues. This then, will help to heightened cell wall permeability thus, will encourage elongation as well as cell division [22].
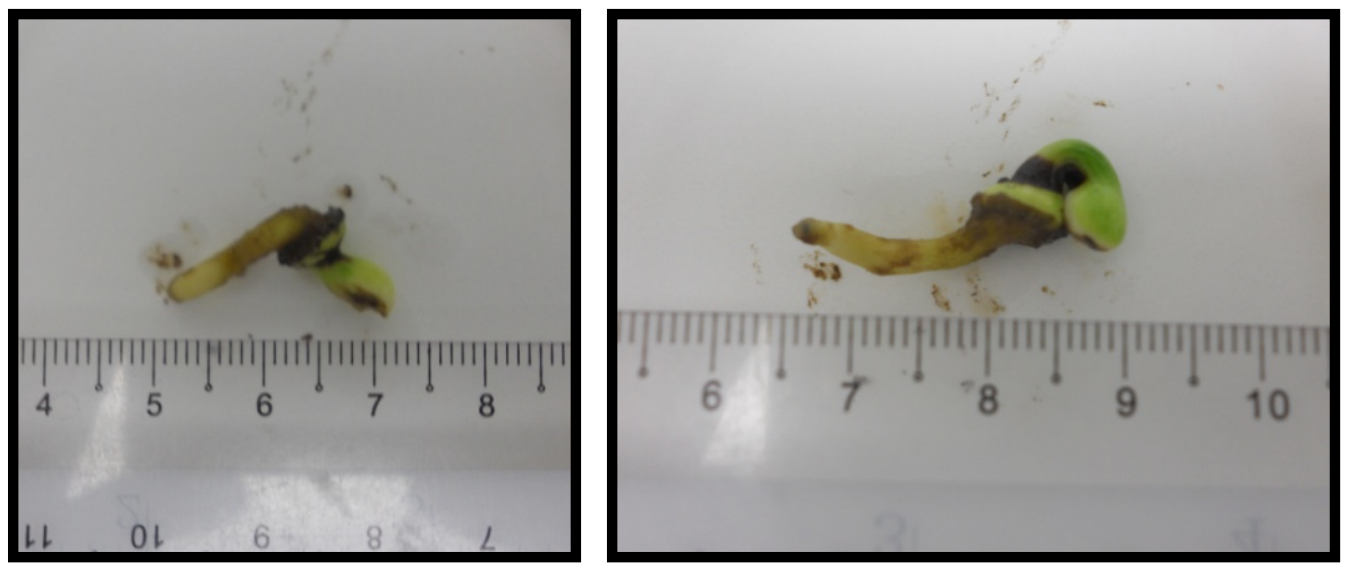

Figure 3. Radical formations from embryo

Table 2. Average length $(\mathrm{cm})$ of radical based on different treatment of KN and IAA for 8 weeks of culture

\begin{tabular}{ccccccccccc}
\hline KN & IAA & T & Week 1 & Week 2 & Week 3 & Week 4 & Week 5 & Week 6 & Week 7 & Week 8 \\
\hline 0 & 0 & 1 & 0 & 0 & 0 & $0.08 \pm 0.09^{\mathrm{a}}$ & $0.34 \pm 0.11^{\mathrm{ab}}$ & $0.52 \pm 0.11^{\mathrm{a}}$ & $0.74 \pm 0.11^{\mathrm{a}}$ & $0.94 \pm 0.11^{\mathrm{a}}$ \\
1 & 0.1 & 2 & 0 & 0 & 0 & $0.10 \pm 0.07^{\mathrm{a}}$ & $0.42 \pm 0.15^{\mathrm{b}}$ & $0.58 \pm 0.08^{\mathrm{a}}$ & $0.80 \pm 0.10^{\mathrm{ab}}$ & $0.96 \pm 0.09^{\mathrm{a}}$ \\
& 0.2 & 3 & 0 & 0 & 0 & $0.10 \pm 0.10^{\mathrm{a}}$ & $0.42 \pm 0.15^{\mathrm{b}}$ & $0.62 \pm 0.11^{\mathrm{a}}$ & $0.82 \pm 0.08^{\mathrm{ab}}$ & $1.00 \pm 1.00^{\mathrm{a}}$ \\
& 0.3 & 4 & 0 & 0 & 0 & $0.06 \pm 0.07^{\mathrm{a}}$ & $0.34 \pm 0.13^{\mathrm{ab}}$ & $0.54 \pm 0.08^{\mathrm{a}}$ & $0.76 \pm 0.09^{\mathrm{a}}$ & $0.94 \pm 0.19^{\mathrm{a}}$ \\
2 & 0.1 & 5 & 0 & 0 & 0 & $0.08 \pm 0.08^{\mathrm{a}}$ & $0.36 \pm 0.11^{\mathrm{ab}}$ & $0.56 \pm 0.05^{\mathrm{a}}$ & $0.76 \pm 0.05^{\mathrm{a}}$ & $0.98 \pm 0.08^{\mathrm{a}}$ \\
& 0.2 & 6 & 0 & 0 & 0 & $0.08 \pm 0.05^{\mathrm{a}}$ & $0.48 \pm 0.08^{\mathrm{b}}$ & $0.64 \pm 0.15^{\mathrm{a}}$ & $0.84 \pm 0.07^{\mathrm{ab}}$ & $1.00 \pm 0.25^{\mathrm{a}}$ \\
& 0.3 & 7 & 0 & 0 & 0 & $0.06 \pm 0.08^{\mathrm{a}}$ & $0.24 \pm 0.11^{\mathrm{a}}$ & $0.58 \pm 0.09^{\mathrm{a}}$ & $0.80 \pm 0.18^{\mathrm{ab}}$ & $0.84 \pm 0.12^{\mathrm{a}}$ \\
3 & 0.1 & 8 & 0 & 0 & 0 & $0.08 \pm 0.08^{\mathrm{a}}$ & $0.36 \pm 0.11^{\mathrm{ab}}$ & $0.56 \pm 0.09^{\mathrm{a}}$ & $0.76 \pm 0.11^{\mathrm{a}}$ & $0.94 \pm 0.11^{\mathrm{a}}$ \\
& 0.2 & 9 & 0 & 0 & 0 & $0.10 \pm 0.05^{\mathrm{a}}$ & $0.48 \pm 0.13^{\mathrm{b}}$ & $0.68 \pm 0.11^{\mathrm{a}}$ & $0.94 \pm 0.12^{\mathrm{b}}$ & $1.20 \pm 0.12^{\mathrm{a}}$ \\
& 0.3 & 10 & 0 & 0 & 0 & $0.06 \pm 0.08^{\mathrm{a}}$ & $0.41 \pm 0.08^{\mathrm{ab}}$ & $0.52 \pm 0.15^{\mathrm{a}}$ & $0.70 \pm 0.15^{\mathrm{a}}$ & $0.90 \pm 0.15^{\mathrm{a}}$ \\
\hline
\end{tabular}

The radical length showed a significant difference in increment except for treatments 4, 7, and 10 (Figure 4). It shows that treatment $4(1 \mathrm{mg} / \mathrm{ml} \mathrm{KN}+0.3 \mathrm{mg} / \mathrm{ml} \mathrm{IAA})$ obtained the highest radical increments with $93.62 \%$ compared to other treatments. This is due to the saturation stage of hormone concentration in the vial. Treatment 4, 7 and 10 did not show a significant difference between treatments however, these treatments showed the highest increment of radical length. The amount of IAA was similar for all three at $0.3 \mathrm{mg} / \mathrm{ml}$ and the only difference is the amount of $\mathrm{KN}$. This indicated that the radical length, growth, and elongation are depending on the IAA concentration. However combination and amount of IAA and $\mathrm{KN}$ might influence the various observations on the elongation of the radical.

The results were supported by, [14] stated that the presence of the IAA in concentrations 1-3 mg/L improved root elongation and produced 1-3 thick single taproots. While the higher concentration of auxin $(5.0 \mathrm{mg} / \mathrm{L})$ was not beneficial and resulted in callus formation at the base of explant. These 
showed that the amount of $0.3 \mathrm{mg} / \mathrm{ml}$ is the optimum amount for these explant and cultivar and any increment after might give a better or adverse effect to the culture. The second highest rise in the radical length, is closely followed by treatment $10(3 \mathrm{mg} / \mathrm{ml} \mathrm{KN}+0.3 \mathrm{mg} / \mathrm{ml} \mathrm{IAA})$ and treatment 7 (2 $\mathrm{mg} / \mathrm{ml} \mathrm{KN}+0.3 \mathrm{mg} / \mathrm{ml} \mathrm{IAA}$ ) with increments of $93.33 \%$ and $92.86 \%$ respectively. The lowest total of increments shows by treatment $2(1 \mathrm{mg} / \mathrm{ml} \mathrm{KN}+0.1 \mathrm{mg} / \mathrm{ml} \mathrm{IAA})$ with only $89.58 \%$. Compared to the plumule tissue, the radical tissue shows a faster growth. The radical diameter shows small difference from its initial measurement while plumule tissue diameter increased as the height increased. The diameter of plumule continued to grow as the plumule bud grown. Different from the plumule, the radical tissue seems to grow only in terms of length, not its diameter. Until week 8, the maximum diameter of radical obtained was only around $0.3 \mathrm{~cm}$. Root length increase caused by the process of cell division at the root tip meristem, then followed by the process of cell lengthening and enlargement. It shows that the concentration of hormone IAA used only effective in radical elongation not to widen the diameter of the embryo. Auxin i.e.: IAA plays a key position in regulating cell expansion through the activation of cell wall synthesis and modification-related genes [21].

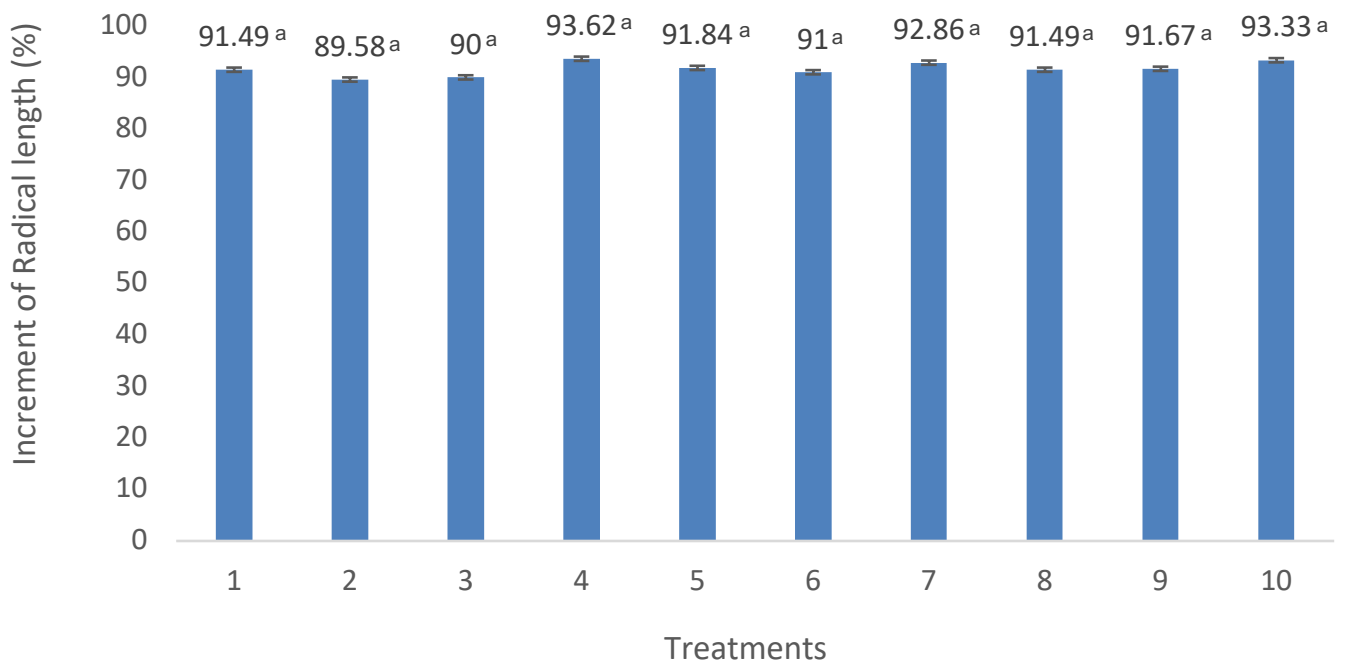

Figure 4. The figure represents the effect of different combination of $\mathrm{KN}$ and IAA treatment on the radical length (\%). The error bars represent the standard deviation of mean measurements for the radical length.

\section{Conclusions}

In conclusion, the optimum hormonal concentrations was obtained in treatment 4 , indicating the hormone in the culture was sufficient for the in vitro regeneration of sugar palm. The plumule and radical growth of embryo explant response differently towards the combination of different concentrations of $\mathrm{KN}$ and IAA hormones. Concisely, KN and IAA hormones have the potential for in vitro plantlet production of sugar palm. The assessment on established in vitro plants need to be done until acclimatization stage to evaluate the stability of the plant. In addition, the effect of the combination hormones used on the genetic fidelity should be accessed using molecular marker for true-to-type plant production.

\section{Conflicts of interest}

The authors declare that there is no conflict of interest regarding the publication of this paper. 


\section{Funding statement}

This research work was supported by Fundamental Research Grant Scheme (FRGS/1/2013/STWN03/UITM/02/3) provided by the Malaysia Ministry of Higher Education (MOHE).

\section{Acknowledgments}

The authors would like to acknowledge the Ministry of Higher Education Malaysia and Universiti Teknologi MARA.

\section{References}

[1] N. S. Abdullah, N. A. Aziz, and A. Awal, "Establishment of sugar palm (Arenga pinnata) shoot from zygotic embryo in ms medium supplemented with different concentrations of benzylaminopurine," Malaysian Applied Biology, vol. 44, no. 4, pp. 31-35, 2015.

[2] J. Sahari, S. Sapuan, E. Zainudin and M. Maleque, "Sugar palm tree: A versatile plant and novel source for biofibres, biomatrices, and biocomposites," Polymers from Renewable Resources, vol. 3 no. 2, pp. 61-77, 2012.

[3] I. Mukhtar, Z. Leman, M. R. Ishak and E. S. Zainudin, "Sugar palm fibre and its composites: A review of recent developments". BioResources, vol. 11, no. 4, pp. 10756-10782, 2016.

[4] J. S. van de, B. A.van den, H. Carlo, E. Martini, J. Roshetko, D. Walden, "Sugar palm ethanol Analysis of economic feasibility and sustainability," Ecofys, Netherland, pp. 57, 2011.

[5] A. B. A. Ahmed, S. Mohajer, E. M. Elnaiem, and R. M. Taha, "In vitro regeneration, acclimatization and antimicrobial studies of selected ornamental plants". In I. of B. Sciences (Ed.), Plant Science, pp. 255-274, 2012.

[6] S. M. Abu-Romman, K. A. Al-Hadid, and A. R. Arabiyyat, "Kinetin is the most effective cytokinin on shoot multiplication from cucumber". Journal of Agricultural Science, vol. 7, no. 10, pp. 159-165, 2015.

[7] M. S. D. Mosleh and A. R. Khetam, "Effect of different concentrations of kinetin and NAA on micropropagation of Gardenia jasminoides”, Journal of Zankoy Sulaimani,vol.13,no. 1, part A, pp. 103-120, 2010.

[8] B. V. Ailenokhuoria, and I. O. Orimadegun, "Effects of indole acetic acid and kinetin on physiological and biochemical properties of two cultivars of pigeon pea (Cajanus caja. L)," International Journal of Plant, Animal and Environmental Sciences, vol. 10, no. 1, pp. 27-34, 2020.

[9] M. Salehifar, B. Rabiei, M. Afshar Mohammadian, and J. Asghari, "Physiological and fluorescence reaction of four rice genotypes to exogenous application of IAA and kinetin under drought stress," Notulae Scientia Biologicae, vol. 9, no. 3, pp. 378-385, 2017.

[10] N. A. Muda, A. Awal, M. Y. Abdullah, and S. Abdullah, "Embryogenic callus induction of Arenga pinnata Wurmb Merr. (Sugar palm) from basal stem explant," International Journal of Advances in Agricultural and Environmental Engineering, vol. 3, no. 1, pp. 106-109, 2016.

[11] N. A. Muda and A. Awal, "Somatic embryogenesis in sugar palm (Arenga pinnata Wurmb Merr.) from zygotic embryo explants," Pertanika Journal of Science \& Technology, vol. 25, pp. 133-144, 2017.

[12] L. H. Soares, D. Dourado Neto, E. B. Fagan, W. F. Teixeira, and I. S. Pereira, "Physiological, phenometric and productive changes in soybean crop due to the use of kinetin," Pesquisa Agropecuária Tropical, vol. 47, no. 1, pp. 80-86, 2017.

[13] S. M. Al-Amri, "Functional activity of some growth regulators on yield components and endogenous hormones of cowpea plants (Vigna sinensis L.)". Agricultural Sciences, vol. 9, no. 10, pp. 1229-1239, 2018.

[14] H. H. Daffalla, E. Abdellatef, E. A. Elhadiand M. M. Khalafalla, "Effect of growth regulators on in vitro morphogenic response of Boscia senegalensis (Pers.) Lam. Poir. using mature zygotic embryos explants," Biotechnology Research International, pp. 1-8, 2011.

[15] S. M. Ansari,A. K. Pandey and U. P. Singh, "Effect of kinetin on growth parameters of cowpea (Vigna unguiculata L.)," Journal of Pharmacognosy and Phytochemistry, vol. 9, no. 5, pp. 628-3. 2020.

[16] W. Rademacher, "Plant growth regulators backgrounds and uses in plant production," Journal of Plant Growth Regulation, vol. 34, no. 4, pp. 845-872, 2015.

[17] L. Ferguson and E.E. Grafton-Cardwell, "Citrus production manual". UCANR Publications, Oakland, University of California, 2014.

[18] M. Flasiński and K. Hąc-Wydro, "Natural vs synthetic auxin: Studies on the interactions between plant hormones and biological membrane lipids," Environmental research, vol. 133, pp. 123-134, 2014.

[19] C. L. Harms and E. S. Oplinger, "Plant growth regulators: their use in crop production," North Central Region Extension Publication 303, Wisconsin, 1988. 
[20] B. V. Ailenokhuoria, "Effects of Indole Acetic Acid and Kinetin on physiological and biochemical properties of two cultivars of pigeon pea (Cajanus caja. L)," International Journal of Plant, Animal and Environmental Sciences, vol. 10, no. 1, pp. 27-34, 2020.

[21] M. Majdaand S. Robert, "The role of auxin in cell wall expansion," International Journal of Molecular Sciences, vol. 19, no. 4, pp. 951, 2018.

[22] T. L. Rost, M. G. Barbour, C. R. Stocking and T. M. Murphy, "Plant biology," California: Wadsworth Publishing Company,1998.

[23] K. Nisak, N. Tutik and I. P. Kristanti, "Pengaruh Kombinasi konsentrasi ZPT NAA dan BAP pada Kultur Jaringan Tembakau Nicotiana tabacum var. Prancak95," Jurnal Sains dan Seni Pomits, vol. 1, pp. 1-6, 2012.

[24] R. Rukmana, "Plant Tissue Culture," (Malang: UMM Press, 2009).

[25] E. Martini, J. M. Roshetko, M. V. Noordwijk, A. Rahmanullah, E. Mulyoutami, L. Joshiand S. Budidarsono,"Sugar palm (Arenga pinnata (Wurmb) Merr.) for livelihoods and biodiversity conservation in the orangutan habitat of Batang Toru, North Sumatra, Indonesia: mixed prospects for domestication," Agroforestry Systems, vol. 86, no. 3, pp. 1-17, 2011.

[26] N. A. Muda and A. Awal, "In vitro germination and acclimatization of sugar palm (Arenga pinnata Wurmb Merr.)," In: Yacob N., Mohd Noor N., Mohd Yunus N., Lob Yussof R., Zakaria S. (eds) Regional Conference on Science, Technology and Social Sciences (RCSTSS 2016). Springer, Singapore, pp. 951-961, 2018. 